\title{
Effects of Calcium chloride and magnesium sulphate treatments on the shelf-life of climacteric banana and non-climacteric pineapple fruits
}

\author{
Jean N. AGHOFACK* and Thomas N. YAMBOU
}

Faculty of Science, Department of Plant Biology, University of Dschang, P.O. Box 67, Dschang, Cameroon

"Correspondence: aghofack@yahoo.fr

\begin{abstract}
Banana (Musa accuminata) and pineapple (Ananas comosus) fruits were treated by dipping in 50,100 and $200 \mathrm{mg} / \mathrm{solutions}$ of $\mathrm{CaCl}_{2}$ and $\mathrm{MgSO}_{4}$ to investigate the effects of the divalent cations $\mathrm{Ca}^{2+}$ and $\mathrm{Mg}^{2+}$ on visually assessed ripening, the quality of pigments, the total lipids content and the water content. Treatments with both salts in the concentration range used retarded the ripening process in bananas and in pineapples. These treatments delayed the chlorophyll a breakdown while the degradation of chlorophyll b was not affected in the peel of the two types of fruits. Treatments with $\mathrm{CaCl}_{2}$ and $\mathrm{MgSO}_{4}$ induced an inhibition of water loss in the peel of banana fruits. In the peel of pineapples, $\mathrm{CaCl}$ treatments led to a decrease in the water content whereas $\mathrm{MgSO}_{4}$ treatments almost did not affect this parameter. $\mathrm{CaCl}_{2}$ solutions with concentrations up to $100 \mathrm{mg} / \mathrm{l}$ induced an increase in total lipids content of the peel of banana fruits while there was no significant change in the content of total lipids in the peel of pineapple fruits. These results indicate that both $\mathrm{Ca}^{2+}$ and $\mathrm{Mg}^{2+}$ may play a role in stabilizing cell membranes, in maintaining cell wall firmness, and in inhibiting chlorophyll a degrading enzymes in the climacteric banana fruits and in the non-climacteric pineapple fruits as well as in inhibiting respiration and breakdown of membrane lipids in climacteric banana fruits.
\end{abstract}

Keywords: Carotenoids, chlorophylls, divalent cations, fruit ripening.

\section{RESUME}

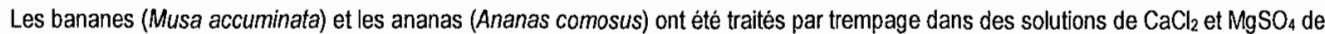
concentrations 50,100 et $200 \mathrm{mg} / \mathrm{l}$. Les effets des cations divalents $\mathrm{Ca}^{2+}$ et $\mathrm{Mg}^{2+}$ sur l'aspect visuel du mûrissement, la qualité des pigments, la teneur en lipides totaux et la teneur en eau ont été étudiès. Les traitements avec ces deux sels ont retardé le mûrissement des bananes et celui des ananas. Ces traitements ont provoqué un ralentissement de la dégradation de la chlorophylle a. Ils n'ont pas eu d'effets sur la dégradation de la chlorophylle $b$ dans la peau des fruits. Les traitements avec des solutions de $\mathrm{CaCl}_{2}$ et $\mathrm{MgSO}_{4}$ ont entraîné une diminution des pertes d'eau dans la peau des bananes. On a observé une baisse de la teneur en eau dans la peau des ananas après traitements avec les solutions de $\mathrm{CaCl}_{2}$ alors que la peau des mêmes fruits traités avec les solutions de $\mathrm{MgSO}_{4}$ avait une teneur en eau comparable à celle des témoins. Les solutions de $\mathrm{CaCl}_{2}$ de concentrations inférieures ou égales à $100 \mathrm{mg} / \mathrm{l}$ ont provoqué une augmentation de la teneur en lipides totaux dans la peau des bananes. Aucun changement significatif n'a été observé dans la teneur en lipides totaux de la peau des ananas traités avec le $\mathrm{CaCl}_{2}$. Ces résultats sont interprètés en termes des rôles des cations $\mathrm{Ca}^{2+}$ et $\mathrm{Mg}^{2+}$ dans le ralentissement du processus du mûrissement suite à une stabilisation des membranes cellulaires, à un maintien de la texture dure de la paroi cellulaire et à une inhibition des enzymes du catabolisme de la chlorophylle a aussi bien chez les fruits climactériques que chez les fruits non-climactériques, ainsi qu'à une inhibition de la respiration et de la dégradation des lipides membranaires chez les bananes.

Mots clés: Caroténoïdes, cations divalents, chlorophylles, mûrissement, fruits.

\section{INTRODUCTION}

Fruits have traditionally been classified into two groups depending on their respiratory behavior, on the rate of ethylene biosynthesis at the onset of ripening, and on the way they respond to ethylene treatment. Climacteric fruits, such as banana, tomato and mango, are characterized by an increase in respiration and ethylene biosynthesis that both coincide with ripening. Nonclimacteric fruits, such as citrus and pineapple, do not exhibit increase in the rate of respiration $[1,2]$. However, in mature citrus fruits ethylene is necessary for natural color change even if it may not be the primary inducer $[3,4]$. The very low rate of ethylene production in mature, detached citrus fruits is associated with the expression of the System II genes of 1-aminocyclopropane-1-carboxylate synthase and ethylene receptor [5].
One of the metabolic characteristics of ripening of both climacteric and non-climacteric fruits is the softening of tissues, which involves the degradation of polysaccharides in the peel and the pulp $[6,7]$. Texture change results from the activities of cell wall hydrolases $[8$, $9,10]$. The activities of cell wall degrading enzymes are induced by increased concentration of endogenous ethylene, independently of its effect on ripening. There is evidence that calcium inhibits the activities of cell wall hydrolases [7, 11]. The divalent cations $\mathrm{Ca}^{2+}$ and $\mathrm{Mg}^{2+}$ play many other physiological roles in plant tissues senescence and in the action of phytohormones. Calcium ions delay the senescence by stabilizing cell membrane and increasing the rigidification of monolayers. The $\mathrm{Ca}^{2+}$ - mediated crosslinking may occur as bridging between phospholipids, between phospholipids and carboxyl tails of embedded 
membrane proteins, and between phosphoilplds and cytoskeletal. Magnesium ion affects the electrostatic crosslinking between membrane components to a lesser extend than calcium ion [12]. There are also several calciumpectate interactions, which make the cell wall firmer [13]. Calcium ion acts as second messenger in coupling many stimulus-response systems. It occupies a pivotal position in plant cell signal transduction pathways, some of which are associated with plant growth regulators $[14,15]$. While intracellular $\mathrm{Ca}^{2+}$ concentration is submicromolar, the concentration of closely related divalent cation $\mathrm{Mg}^{2+}$ is millimolar. Despite the concentration difference that would favor $\mathrm{Mg}^{2+}$ cellular processes often display an enormous selectivity for $\mathrm{Ca}^{2+}$ [15].

Contrarily to the generally known retarding effects of $\mathrm{Ca}^{2+}$ on plant leaves senescence [12] and ripening of mango fruits [16], it has recently been reported that treatment by pressure infiltration with $4 \% \mathrm{CaCl}_{2}$ reduces the firmness and accelerates the ripening of banana fruits [17]. It is well known that the two different methods of treatment with phytohormones by dipping and by pressure infiltration lead to contrasting results, although pressure infiltration gives uniform distribution of the active substance through the fruit $[18,19] .4 \% \mathrm{CaCl}_{2}$ solution might also be highly concentrated and induced an opposite effect of $\mathrm{Ca}^{2+}$. To the best of our knowledge, no experimental work exists on the influence of $\mathrm{Mg}^{2+}$ treatment on the ripening of bananas. Moreover, no study has been done on the effects of $\mathrm{Ca}^{2+}$ and $\mathrm{Mg}^{2+}$ treatments on the ripening of pineapple, a non-climacteric fruit. The present work was undertaken to examine the effects of treatments by dipping in $\mathrm{CaCl}_{2}$ and $\mathrm{MgSO}_{4}$ solutions at different concentrations lower than $4 \%$ on the ripening of banana and pineapple fruits.

\section{MATERIALS AND METHODS}

\section{Plant materials}

Banana fruits (Musa accuminata Colla var. William) were donated by the Cameroon Banana Producing Company (SBM-PH-SPNP) in Loum. All bananas were from second hands of bunches. Pineapple fruits (Ananas comosus (L.) Merr. of the Cayenne group) were harvested from a farm in Lowe (Mungo Division). They were of the third class (1.3 to $1.5 \mathrm{~kg}$ fresh weight). Bananas and pineapples were dipped in $50 \mathrm{mg} / \mathrm{l}, 100 \mathrm{mg} / \mathrm{l}$ and $200 \mathrm{mg} / \mathrm{l}$ $\mathrm{CaCl}_{2}$ or $\mathrm{MgSO}_{4}$ solutions. Untreated fruits were used as control.

\section{Assessment of fruit ripening stages}

The different stages of ripeness of fruits (1 to 7) were visually assessed according to Anon [20].

\section{Analysis of pigments}

Pigments were extracted from fresh peel of fruits (12 g) with $10 \mathrm{ml}$ of acetone. A spatula of $\mathrm{CaCl}_{2}$ was added to the extract. After homogenization the extract was allowed to stand for $30 \mathrm{~min}$. The green acetone phase was collected and used as total plgment extract. Indlvidual chlorophylls and carotenoids were fractionated on aluminium sheets precoated with silica ge ${ }_{60} \mathrm{~F}_{254}$ (Merck $^{\mathrm{TM}}$, Germany) by thin layer chromatography. The mobile phase was a mixture of benzene, chloroform and acetone (6/3/2, $v / v / v)$.

\section{Determination of water and total lipid content}

$250 \mathrm{mg}$ of fresh peel of fruits were dried in an oven at $135{ }^{\circ} \mathrm{C}$ for $6 \mathrm{~h}$. They were then weighted for the determination of dry matter weight. The water content in the peel was calculated using fresh and dry matter weight according to Chapman [21]

Total lipids were extracted from fresh peel of fruits using a 1.5/1/1 (v/v/V) mixture of chloroform, methanol and water. The extract was allowed to stand for $45 \mathrm{~min}$. The chloroform phase was then transferred into a vial of known weight. After complete evaporation of the chloroform the vial was weighed again for the determination of total lipid content.

\section{Statistical analysis}

Statistical analyses were performed with the aid of SPSS for MS WINDOWS. Group comparisons were made using ANOVA. A $p$ value of $P<0.05$ was considered as statistically significant.

\section{RESULTS}

The visual assessment of stages of ripeness showed that salt-treated bananas and pineapples were still respectively at stages 2 and 4 of ripening scale while untreated fruits were at stage 7 . Thin layer chromatography of pigment extract from peel of fruits revealed that both treated bananas and pineapples contained chlorophyll a and carotenoids while untreated fruits contained only carotenoids. It is noteworthy that the peel of green unripe fruits contained chla, chlb and corotenoids (Fig. 1 \& 2).
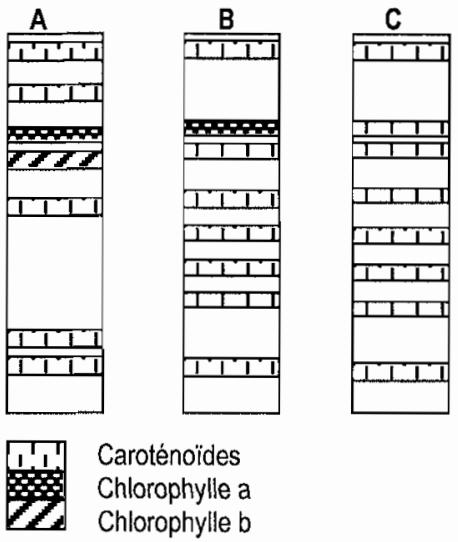

Figure 1: Chromatograms of pigments extracted from the peel of banana fruits. $A=$ control fruits at stage 1 of ripening; $B=$ treated fruits at stage $2 ; \mathrm{C}=$ control fruits at stage 7 . 
Measurement of the water content in the peel of fruits showed that untreated bananas contained significantly less amount of water than $\mathrm{CaCl}_{2}$-treated fruits whereas the reverse relationship was observed in the peel of pineapple fruits. The water contents were $89 \%, 89 \%$ and $89 \%$ in the peel of bananas treated with 50,100 and 200 $\mathrm{mg} / \mathrm{l} \mathrm{CaCl} 2$ solutions while the peel of control fruits contained $81 \%$ (Fig. 3). The water content in the peel of untreated pineapple fruits was $88 \%$ while the peel of pineapples treated with 50,100 and $200 \mathrm{mg} / \mathrm{l} \mathrm{CaCl} 2$ solutions contained respectively $85 \%, 85 \%$ and $86 \%$ water (Fig. 3).
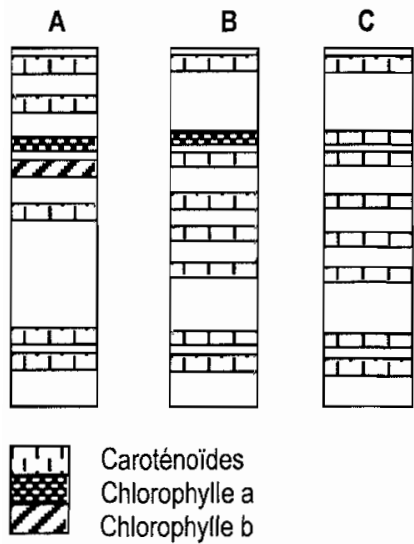
Caroténoïdes
Chlorophylle a
Chlorophylle b

Figure 2: Chromatograms of pigments extracted from the peel of pineapple fruits. $A=$ control fruits at stage 1 of ripening; $B=$ treated fruits at stage $2 ; C=$ control fruits at stage 7 .

No significant differences were observed between the effects of different $\mathrm{CaCl}_{2}$ and $\mathrm{MgSO}_{4}$ concentrations used. The effects of $\mathrm{MgSO}_{4}$ treatments on water content in the peel of bananas followed similar trends as observed with $\mathrm{CaCl}_{2}$ treatments (Fig. 4). However, there were no significant differences between the water contents in the peel of pineapples treated with 50,100 and $200 \mathrm{mg} / \mathrm{l}$ $\mathrm{MgSO}_{4}$ solutions, and in the peel of control fruits. Furthermore, no dose-dependent effect of $\mathrm{MgSO}_{4}$ treatments on water content in the peel of pineapples could be observed (Fig. 4).

The determination of total lipid content in the peel of fruits showed that treatment of bananas with 50 and 100 $\mathrm{mg} / \mathrm{CaCl} 2$ solutions resulted in an increase of respectively $32 \%$ and $40 \%$ while treatment with $200 \mathrm{mg} / \mathrm{CaCl}$ solution did not affect this parameter. No significant change was observed in the total lipid content in the peel of pineapples after treatments with different solutions of $\mathrm{CaCl}_{2}$ (Fig. 5).

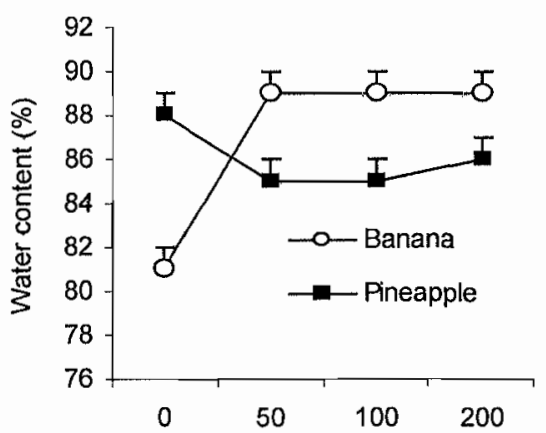

Calcium chloride concentration ( $\mathrm{mg} / \mathrm{l}$ )

Figure 3: Water content in the peel of banana and pineapple fruits during ripening after treatment with different concentrations of $\mathrm{CaCl}_{2}$.

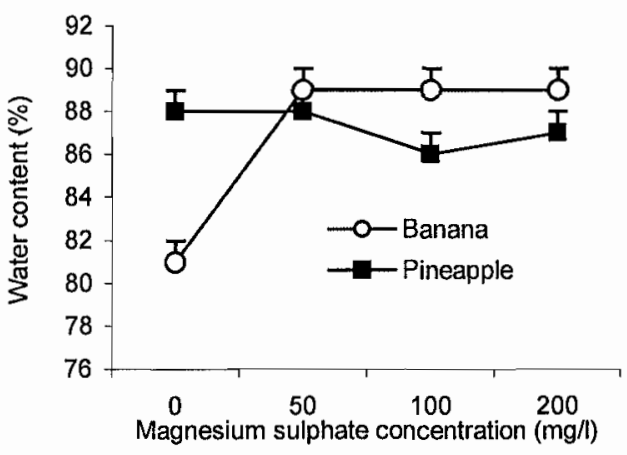

Figure 4 : Water content in the peel of banana and pineapple fruits during ripening after treatment with different concentrations of $\mathrm{MgSO}_{4}$.

\section{DISCUSSION AND CONCLUSIONS}

The results showed that treatments with $\mathrm{Ca}^{2+}$ and $\mathrm{Mg}^{2+}$ salts in the concentration range from $50 \mathrm{mg} / \mathrm{l}$ to $200 \mathrm{mg} / \mathrm{l}$ retarded the visually assessed ripening. At the metabolic level the chlb breakdown was not affected by these treatments whereas there was a delay in chla degradation and water loss, and an increase in the total lipid content in the peel. $\mathrm{Ca}^{2+}$ and $\mathrm{Mg}^{2+}$ cations would have stabilized cell membranes and maintained the cell wall firm by mediating cross-linking between their components [12, 13]. These cations are also known to play an important role in the inhibition of cell degrading enzymes [11]. The pigment composition in the peel of green unripe fruits and in green plant leaves is almost the same with chla, chlb and carotenoids being the major components. The yellowing of senescent leaves is due to unmasking and partial retention of carotenoids [22]. During fruit ripening there is a 
degradation of chlorophyll, retentlon of pre-existing carotenoids and new synthesis of other yellow pigments $[23,24,25]$. Isolation, functional expression and characterization of cDNA encoding chlorophyllase in citrus fruits have been reported [26]. Chlorophyllase is an enzyme catalyzing the first step of chlorophyll breakdown pathway. Chlorophyllase, Mg-chelatase, methyl esterase, peroxidase, lipoxygenase and phenol oxidase have been suggested as catalysts for chlorophyll bleaching in senescing tissues $[7,22]$. Indeed, lipoxygenase and peroxidase are believed to be $\mathrm{Ca}^{2+}$ stimulated $[12,27]$. The detailed mechanisms whereby $\mathrm{CaCl}_{2}$ and $\mathrm{MgSO}_{4}$ treatments delayed the degradation of chla but not that of chlb in the peel of ripening banana and pineapple fruits are still to be elucidated. Since chla is predominantly found in the reaction center while chlb is exclusively an antenna pigment of the photosystems $[28,29]$, there might be a specific $\mathrm{Ca}^{2+}$ and $\mathrm{Mg}^{2+}$ independent destruction of the antenna zone. Moreover, some experimental indications exist on the conversion of chlb to chla prior to chlorophyll degradation in de-greening plant leaves [30].

$\mathrm{CaCl}_{2}$ and $\mathrm{MgSO}_{4}$ treatments induced an inhibition of water loss in the peel of banana fruits, indicating that $\mathrm{Ca}^{2+}$ and $\mathrm{Mg}^{2+}$ inhibited water loss through transpiration by stabilizing cell membranes and rendering cell wall firmer [12]. Furthermore, the inhibition of respiration by $\mathrm{Ca}^{2+}$ that delays the transformation of starch into reducing sugars could retard the increase of osmotic potential in the pulp and thus inhibit the movement of water from peel to pulp $[31,32]$. The peel of $\mathrm{CaCl}_{2}$ treated pineapples contained less water than the peel of untreated fruits and there was no significant effect of $\mathrm{MgSO}_{4}$ treatments on pineapples. This could be due to the fact that in non-climacteric fruits, such as pineapple, there is no measurable increase in the rate of respiration at onset of ripening $[1,2]$. Further studies should clarify the metabolic basis of these differential effects of $\mathrm{CaCl}_{2}$ and $\mathrm{MgSO}_{4}$ treatments on the water content in the peel of bananas and pineapples.

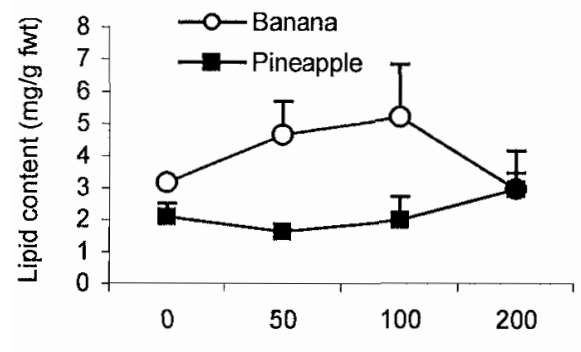

Calcium chloride concentration (mg/l)

Figure 5 : Lipid content in the peel of banana and pineapple fruits during ripening after treatment with different concentrations of $\mathrm{CaCl}_{2}$.
Treatments with $\mathrm{CaCl}_{2}$ solutions up to $100 \mathrm{mg} / \mathrm{l}$ led to an increase in the content of total lipids in the peel of bananas while there was no significant effect of salt treatments on this parameter in peel of pineapples. These results could be related to the difference in the climacteric and non-climacteric nature of both fruits. Since most of plant lipids are constituents of membranes and are important in the modulation of many physiological processes including senescence $[33,34]$, a new synthesis or an inhibition of their breakdown may support the delaying effects of salt treatments on fruit ripening.

\section{REFERENCES}

1. Wills R., McGlasson B., Graham D. and Joyee D. 1998. Postharvest: An introduction to Physiology and handling of fruits, vegetables and ornamentals. Wallingford: Center for Agriculture and Biosciences. 350p.

2. Burg S. P. and Burg E. A. 1965. Relationships between ethylene production and ripening in bananas. Botanical Gazette 126: 200-204.

3. Purvis A. C. and Barmore C. R. 1981. Invoivement of ethylene in chlorophyll degradation in peel of citrus fruits. Plant Physiology 68: 854-856.

4. Apelbaum A., Goldschmidt E. E. and Ben-Yehoshua S. 1976. Involvement of endogenous ethylene in the induction of color in Shamouti oranges. Plant Physiology 57: 856-838.

5. Katz E. , Lagunes P. M., Riov J., Weiss D. and Goldschmidt E. E. 2004. Molecular and physiological evidence suggests the existence of a system II-like pathway of ethylene production in non-climacteric citrus fruit. Planta 219(2): 243-252.

6. Mafra I., Lanza B., Reis A., Marsilio V., Campestre C., De Angelis M. and Coimbra M. A. 2001. Effects of ripening on texture, microstructure and cell wall polysaccharide composition of olive fruit (Olea europaea). Physiologia Plantarum 111: 439-447.

7. John P. and Marchal J. 1995. Ripening and biochemistry of fruit. In: S. Gowen (ed.). Bananas and Plantains. Chapman \& Hall: 434-467.

8. Marin-Rodriguez M. C., Smith D. L., Manning $K_{\text {, }}$ Ochard J. and Seymour G. B. 2003. Pectate lyase gene expression and enzyme activity in ripening banana fruit. Plant Molecular Biology 56(16): 851. 857.

9. Fischer R. L. 1991. Cell wall hydrolases in fruit ripening. Annual Review of Plant Physiology and Molecular Biology 42: 675-702.

10. Kindl H. 1987. Biochemie der Pflanzen. Berlin: Sringer-Veralg. 379p.

11. Brady C. J. 1987. Fruit ripening. Annual Review of Plant Physiology 38: 155-178.

12. Leshem $Y, Y$. 1991. Plant membrane senescence. In: C. Penel and H. Greppin (eds). Plant signaling, 
plasma membrane and change of state. University of Geneva Press: $31-59$.

13. Carpita N. and McCann M. 2000. The cell wall. In: B. B. Buchanan, W. Gruissen and R. L. Jones (eds). Biochemistry and molecular biology of plants. American Society of Plant Physiologists: 52-108.

14. Trewavas A. 2000. Signal perception and transduction. In: B. B. Buchanan, W. Gruissen and R. L. Jones (eds). Biochemistry and molecular biology of plants. American Society of Plant Physiologists: 930-987.

15. Hepler P. K. and Wayne R. O. 1985. Calcium and plant development. Annual Review of Plant Physiology 36: 397-439.

16. Singh Z., Janes L. and Tan S. C. 2000. Effects different surfactants on calcium uptake and its effects on fruit ripening, quality and postharvest storage of mango under modified atmosphere packaging. ISHS Acta Horticulturae 509(2): 102-105.

17. Perera N. A. and Karunaratne A. M. 2002. Postharvest calcium chloride treatments do not help to increase shelf-life of bananas. Fruits 57(2): 87-94.

18. Vendrell M. 1970. Acceleration of ripening in banana fruit tissue by gibberellic acid. Australian Journal of Biological Sciences 23: 553-559.

19. Vendrell M. 1970. Relationship between internal distribution of exogenous auxins and accelerated ripening of banana fruits. Australian Journal of Biological Sciences 23: 1133-1142.

20. Anon L. 1961. Banana ripening manual. Boston: Fruit Dispatch Co. 24p.

21. Chapman S. B. 1976. Methods in Plant ecology. Physiology and nutrition. Oxford: Blackwell Scientific Publications. 573p.

22. Matile P. and Hörtensteiner S. 1999. Chlorophyll degradation. Annual Review of Plant Physiology and Molecular Biology of Plants 50: 67-95.

23. Aghofack-Nguemezi J., Schoch S. and Graefe U. 2002. Effects of coconut oil and palm kernel oil treatments on several parameters in ripening climacteric and non-climacteric fruits. In: SOCAB

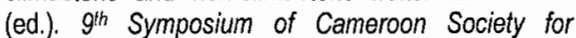
Biochemistry and Molecular Biology. Yaoundé June 7-8: 12.
24. Hornero-Mendez $D$. and Minguez-Mosquera M. I. 2000. Xanthophyll esterification accompanying carotenoid overaccumulation in chromoplasts of Capsicum annuum ripening fruits is a constitutive process and useful for ripening index. Journal of Agriculture and Food Chemistry 48(5): 1617-1622.

25. Su'bagio A., Morita N. and Sawada S. 1996. Carotenoids and their fatty acid esters in the banana peel. Journal of Nutritional Sciences and Vitamology 42(6): 553-566.

26. Jacob-Wilk D., Holland D., Goldschmidt E. E., Riov J. and Eyal Y. 1999. Chlorophyll breakdown by chlorophyllase: isolation and functional expression of chlase1 gene from ethylene - treated citrus fruits and its regulation during development. Plant Journal 20(6):653 - 661 .

27. Penel C. 2000. The peroxidase system in higher plants. In: H. Greppin, C. Penel, W. J. Broghton and R. Strasser (eds). University of Geneva Press: 359367.

28. Lawlor D. W. 1990. Photosynthese: StoffwechselKontrolle-Physiologie. Stuttgart: Georg Thieme Verlag. 550p.

29. Rüdiger, $W$. and Schoch S. 1989. Abbau von Chlorophyll. Natumissenschaften 76: 453-457.

30. Porra R. J. and Scheer H. 2000. ${ }^{18} \mathrm{O}$ and mass spectrometry in chlorophyll research: Derivation and loss of oxygen at the periphery of chlorophyll macrocycle during biosynthesis, degradation and adaptation. Photosynthesis Research 66: 159-175.

31. Ngalani J. A., Tchango Tchango J. and Reynes $M$. 1999. Starch and sugar transformation during ripening of banana and plantain cultivars grown in Cameroon. Tropical Sciences 39: 115-119.

32. Cordenunsi B. R. and Lajolo F. M. 1995. Starch breakdown during ripening: Sucrose synthase and sucrose phosphate synthase. Journal of Agriculture and Food Chemistry 43: 347-351.

33. Quinn P. J. and Williams W. P. 1983. The structural role of lipids in photosynthetic membranes. Biochemistry and Biophysics Acta 737: 223-266.

34. Raison J. K. 1980. Membrane lipids: Structure and function. In: P. K. Stumpf (ed.). Lipids: structure and Function. Academic Press: 57-83. 